\title{
Strategi Pemasaran Produk Kerajinan Eceng Gondok Di Desa Banyu Hirang Kecamatan Amuntai Selatan Kabupaten Hulu Sungai Utara (Studi Kasus Kelompok Usaha Bersama (KUB) “ Kembang Ilung”)
}

\section{(Marketing Strategy Of Eceng Gondok Handicraft Product In Banyu Hirang Vilage, Distric Of Amuntai Selatan Hulu Sungai Utara (Case Study Usaha Bersama Group“ Kembang Ilung”))}

\author{
Yani Warliyanti \\ Program Studi Agribisnis, Sekolah Tinggi Ilmu Pertanian Amuntai \\ yaniwarliyanti89@gmail.com
}

\begin{abstract}
ABSTRAK
Penelitian ini bertujuan (i) mengetahui kekuaatan, kelemahan, ancaman dan peluang, serta (ii) mengetahui bagaimana strategi pemasaran Kelompok Usaha Bersama (KUB) "Kembang Ilung"di Desa Banyu Hirang Kabupaten Hulu Sungai Utara. Metode kasus digunakan pada penelitian ini, pihak yang menjadi responden ada dua, yaitu pihak internal adalah pengelola KUB dan anggota yakni pengrajin eceng gondok, sedangkan pihak eksternal adalah Disparindagkop. Kabupaten Hulu Sungai Utara. Hasil penelitian menunjukkan matriks IFE sebesar 2,592 dan matrik EFE sebesar 2,674 dimana pada matrik IE menempatkan KUB "Kembang Ilung" pada kuadran V, yaitu strategi Hold and Maintain (jaga dan pertahankan). Strategi yang dapat diterapkan pada posisi ini adalah strategi penetrasi pasar dan pengembangan produk.
\end{abstract}

Kata kunci: Kelompok, usaha, bersama, eceng gondok, matriks.

\section{ABSTRACT}

This study aims (i) to know the strength, weaknesses, threats and opportunities, and (ii) to find out how the marketing strategy of the "Kembang Ilung" Joint Business Group (KUB) in Banyu Hirang Village, Hulu Sungai Utara Regency. The case method is used in this study, there are two parties who are respondents, namely the internal party is the manager of the KUB and the member is the water hyacinth craftsman, while the external party is Disparindagkop. Hulu Sungai Utara Regency. The results showed that the IFE matrix was 2.592 and the EFE matrix was 2.674 where the IE matrix placed the Kembang Ilung in the V quadrant, namely the Hold and Maintain strategy (keep and maintain). The strategy that can be applied to this position is the strategy of market penetration and product development.

Keywords: Group, business, together, water hyacinth, matrix.

\section{PENDAHULUAN}

Indonesia merupakan negara tropis yang memiliki keanekaragaman hasil alam yang mampu berperan dalam mendukung kehidupan masyarakat. Namun, kekayaan alam tersebut baru akan memberikan nilai guna yang lebih apabila diolah menjadi aneka macam produk. Salah satu potensi alam yang dapat dimanfaatkan agroindustri untuk meningkatkan pendapatan masyarakat adalah tanaman eceng gondok.

Hingga saat ini, di Indonesia sudah banyak daerah yang mampu mengembangkan kerajinan eceng gondok, antara lain di Purbalingga, Yogyakarta, Solo, Lampung, Cirebon, Surabaya dan Bali. Bahkan sebagian barang-barang kerajinan eceng gondok dengan model dan kualitas tertentu, banyak di ekspor ke Eropa dan Amerika Serikat yang semakin tertarik dengan barang-barang produksi dari bahanbahan alami (Priastuti, 2011).

Salah satu kabupaten di Kalimantan Selatan yang memanfaatkan potensi eceng gondok yang melimpah adalah Kabupaten Hulu Sungai Utara yaitu Kecamatan Paminggir, Babirik, Sungai Pandan, Danau Panggang dan Kecamatan Amuntai Selatan. Desa Banyu Hirang mempunyai Kelompok 
Usaha Bersama (KUB) yang merupakan pelopor kerajinan eceng gondok di HSU bahkan para perajinnya sering dilibatkan untuk memberi pelatihan kepada perajin di desa lain. Persedian bahan baku kerajinan berupa eceng gondok banyak terdapat di perairan di Desa Banyu Hirang yang awalnya dianggap masyarakat sebagai gulma sekarang sudah menjadi sesuatu yang berguna dan bernilai ekonomis. Eceng Gondok digunakan masyarakat sebagai bahan baku untuk kerajinan, diantaranya untuk pembuatan tas, tempat sampah, tempat tissue, sandal, mebel. Perkembangan industri kerajinan eceng gondok di Desa Banyu Hirang Kecamatan Amuntai selatan Kabupaten Hulu Sungai Utara tahun 2007 2011 dapat dilihat pada Tabel 1.

Tabel. 1 Data Perkembangan Industri Anyaman Eceng Gondok di Desa Banyu Hirang

\begin{tabular}{lccccc}
\hline \multirow{2}{*}{ Nama Komoditi } & \multicolumn{5}{c}{ Hasil Industri Anyaman Eceng Gondok (Unit) } \\
\cline { 2 - 6 } & 2007 & 2008 & 2009 & 2010 & 2011 \\
\hline $\begin{array}{l}\text { Anyaman Eceng } \\
\text { Gondok }\end{array}$ & 200 & 500 & 800 & 1000 & 1800 \\
\hline
\end{tabular}

Sumber: Anonim, 2011

Adapun tujuan dari penelitian ini adalah (i) melakukan analisis SWOT untuk mengetahui kekuatan dan kelemahan serta ancaman dan peluang Kelompok Usaha Bersama (KUB) "Kembang Ilung"di Desa Banyu Hirang Kecamatan Amuntai Selatan Kabupaten Hulu Sungai Utara, dan (ii) mengetahui bagaimana strategi pemasaran Kelompok Usaha Bersama (KUB) "Kembang Ilung" di Desa Banyu Hirang Kecamatan Amuntai Selatan Kabupaten Hulu Sungai Utara.

\section{METODE PENELITIAN}

\section{Tempat dan Waktu Penelitian}

\section{Lokasi dan Waktu Penelitian}

Penelitian dilakukan pada Kelompok Usaha Bersama (KUB) "Kembang Ilung" anyaman eceng gondok di Desa Banyu Hirang Kecamatan Amuntai Selatan. Penelitian dilakukan dari bulan Februari 2012 - Mei 2012.

\section{Jenis dan Sumber Data}

Dalam penelitian ini diperlukan data primer dan data sekunder. Data primer diperoleh dari wawancara langsung dengan responden. Data sekunder diperoleh datadata instansi terkait melalui dokumen yang tersedia pada instansi yang bersangkutan.

\section{Metode Pengumpulan Data}

Peneliti menggunakan metode studi kasus pada penelitian ini yaitu pada Kelompok Usaha Bersama (KUB) "Kembang Ilung" Anyaman Eceng Gondok Desa Banyu Hirang Kecamatan Amuntai Selatan Kabupaten Hulu Sungai Utara.

Pihak yang menjadi responden dalam penelitian ini dikelompokkan menjadi 2 yaitu: pihak internal yaitu pengelola Kelompok Usaha Bersama "Kembang Ilung" yaitu, Ketua KUB "Kembang Ilung dan anggota KUB yakni pengrajin eceng gondok. Pihak eksternal adalah pihak yang berada di luar KUB "Kembang Ilung”, tetapi mengetahui secara jelas mengenai kerajinan eceng gondok di Desa Banyu Hirang yaitu, Kepala Dinas Koperasi Perindustrian dan Perdagangan dan Kabid Industri Kab. Hulu Sungai Utara.

\section{HASIL DAN PEMBAHASAN}

Berdasarkan hasil analisis faktor internal dan eksternal pada usaha kerajinan eceng gondok, maka dapat diidentifikasi kekuatan, kelemahan, peluang dan ancaman yang berpengaruh terhadap pemasaran kerajinan eceng gondok di KUB "Kembang Ilung".

Tabel 2. Identifikasi faktor internal KUB "Kembang Ilung” 


\section{Kekuatan}

- Lokasi usaha strategis

- Adanya loyalitas pelanggan

- Kontinuitas produksi

- Kualitas bahan baku baik

- Memiliki ciri khas produk
Kelemahan

- Sistem manajemen masih sederhana

- Kualitas SDM masih rendah, terbatas dan kurang fokus

- Kurangnya pengembangan pasar dan penggunaan teknologi informasi (internet).

- Variasi desain produk kurang dan produksi masih tergantung pada alam sehingga kapasitas produksi belum optimal

- Pengelolaan keuangan/pembukuan belum tersusun rapi (sistem akuntansi belum baik)

Tabel 3.Identifikasi faktor eksternal KUB "Kembang Ilung”

\section{Peluang}

- Pengadaan pelatihan danpemeran serta dukungan pemerintah untuk mencintai produk lokal

- Hubungan baik dengan pemasok

- Perkembangan teknologi informasi yang makin maju

- Ketersediaan bahan baku melimpah

- Pertumbuhan ekonomi Indonesia yang semakin stabil sehingga adanya peluang ekspansi pemasaran
Ancaman

- Adanya produk substitusi

- Kondisi iklim yang tidak mendukung

- Sikap masyarakat yang kurang mencintai produk lokal

- Naiknya harga BBM sehingga daya beli pelanggan menurun

- Ketidakpuasan pembeli terhadap produk

\section{Perumusan Alternatif Strategi}

Tabel. 4 Matrik IFE KUB “Kembang Ilung”

\begin{tabular}{lccc}
\hline Faktor Strategi Internal & Bobot & Rating & $\begin{array}{c}\text { Skor } \\
\text { Pembobotan }\end{array}$ \\
\hline Kekuatan & & & \\
\hline - Memiliki ciri khas produk & 0,10 & 3 & 0,30 \\
\hline - Lokasi strategis & 0,067 & 4 & 0,268 \\
\hline - Kualitas bahan baku baik & 0,072 & 3 & 0,216 \\
\hline - Kountinuitas produksi & 0,078 & 3 & 0,234 \\
\hline - Adanya loyalitas pelanggan & 0,105 & 4 & 0,42 \\
\hline $\begin{array}{l}\text { Kelemahan } \\
\text { - Sistem manajemen masih sederhana }\end{array}$ & 0,094 & 2 & 0,188 \\
$\begin{array}{l}\text { - Kualitas SDM masih rendah, terbatas dan } \\
\text { kurang focus }\end{array}$ & 0,144 & 2 & 0,288 \\
$\begin{array}{l}\text { - Kurangnya pengembangan pasar dan } \\
\text { penggunaan teknologi informasi (internet) }\end{array}$ & 0,139 & 2 & 0,278 \\
\hline
\end{tabular}


- Variasi desain kurang dan produksi masih $0,122 \quad 2 \quad 0,244$ tergantung dari alam sehingga kapasitas belum optimal

\begin{tabular}{llll}
\hline - Pengelolaan/pembukuan keuangan belum rapi & 0,078 & 2 & 0.156 \\
\hline Total & 1.000 & & 2,592 \\
\hline
\end{tabular}

Tabel. 5 Matrik EFE KUB "Kembang Ilung”

Faktor Strategi Eksternal Bobot Rating $\begin{gathered}\text { Skor } \\ \text { Pembobotan }\end{gathered}$

Peluang

- Pengadaan pelatihan dan pameran serta $0,133 \quad 4 \quad 0.532$ dukungan pemerintah untuk mencintai produk lokal

\begin{tabular}{lllll}
\hline - & Hubungan dengan pemasok baik & 0,117 & 4 & 0.468
\end{tabular}

- $\quad$ Ketersediaan bahan baku terjamin $\quad 0,050 \quad 4 \quad 0.20$

- Adanya peluang ekspansi pemasaran $\quad 0,072 \quad 4 \quad 0.288$

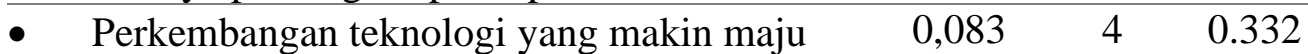

Ancaman

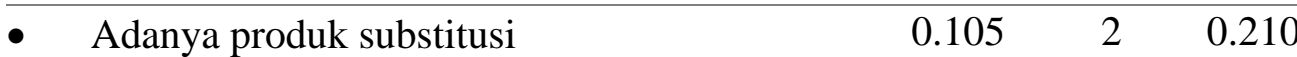

$\begin{array}{llll}\text { - } \quad \text { Kondisi iklim yang kurang mendukung } & 0.094 & 2 & 0.188\end{array}$

\begin{tabular}{lllll}
\hline & Sikap masyarakat yang kurang mencintai prod & 0.122 & 1 & 0.122
\end{tabular} uk lokal

\begin{tabular}{lllll}
\hline - & Naiknya harga BBM dan daya beli pelanggan & 0.072 & 2 & 0.144
\end{tabular} menurun

\begin{tabular}{llll}
\hline - $\quad$ Ketidakpuasan konsumen terhadap produk & 0.150 & 1 & 0.150 \\
\hline Total & 1.000 & & 2.634
\end{tabular}

$1.000 \quad 2.634$

Matrik IE

Nilai total skor matrik IFE sebesar 2,592 sedangkan matrik EFE sebesar 2,634 sehingga menempatkan perusahaan pada posisi sel $\mathrm{V}$ dalam matrik IE. Hal ini dapat dilihat pada Gambar 2.

IFE yang Diberi Bobot

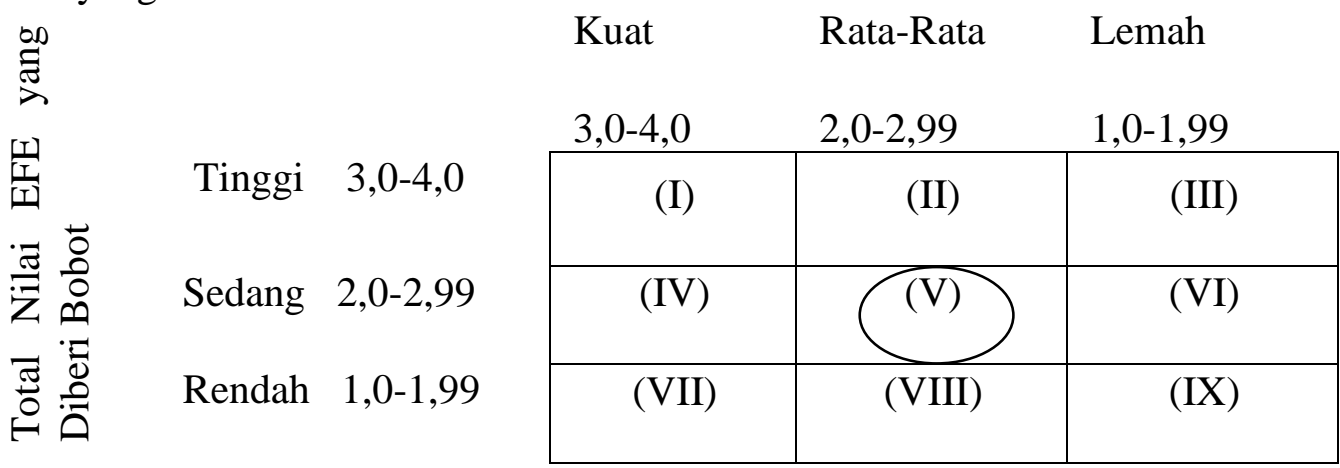

Gambar 2. Matriks Internal-Eksternal (IE)

Posisi ini disebut Hold and Maintain (jaga dan pertahankan). Strategi yang tepat digunakan pada posisi ini adalah strategi penetrasi pasar dan pengembangan produk (David, 2010).
Bauran Pemasaran Kerajinan Eceng Gondok di KUB "Kembang Ilung” Strategi Produk

KUB "Kembang Ilung" dalam menghadapi permintaan produk kerajinan eceng gondok dalam jumlah yang besar 
diperlukan peningkatan kemampuan produksi dan dengan cara memperbaiki teknik produksi agar lebih efisien serta peningkatan produktivitas pengrajin;meningkatkan kualitas mutu produk dengan kreatis dalam mendesain; menciptakan produk yang unik jeli melihat tren yang disukai konsumen yang terjadi pada saat itu diperlukan pengembangan variasi produk baru agar konsumen tidak mengalami kebosanan pada produk yang telah tersedia; Memberikan kemasan terhadap produk dan disertai pemberian label dapat mempengaruhi konsumen dan alat untuk meningkatkan atau mempertahankan penjualan. Kemasan bermanfaat bukan hanya sebagai pelindung produk, tetapi juga dapat memberi kesan mutu dan kualitasnya baik sehingga dapat menarik perhatian konsumen. Pemberian merek atau label tertentu, misalnya mencantumkan tulisan "Kembang Ilung" Made in Amuntai dalam kemasan produk berfungsi untuk mengidentifikasi produknya dan yang membedakan dengan produk saingan; Memberikan pelayanan mencakup pelayanan sewaktu penawaran produk, pelayanan dalam pembelian, pelayanan sewaktu penyerahan produk, dan pelayanan setelah/purna jual.

\section{Strategi Harga}

Tingkat harga tidak selalu sama dan dapat berubah dari waktu ke waktu. Dalam hal ini, diperlukan adanya kesesuaian harga yang ditetapkan dengan daya beli konsumen agar lebih ekonomis dengan tetap menjaga mutu produk. Menekan biaya produksi yang lebih efisien untuk mendapatkan keuntungan yang lebih tinggi atau dapat mempertahankan harga di level yang disukai konsumen sehingga konsumen tidak beralih ke produk sejenis dengan harga lebih murah. KUB "Kembang Ilung" dapat memberikan potongan harga kepada pembeli yang membeli dalam jumlah besar atau kepada pembeli yang membayar dengan tunai. Selain itu syarat-syarat pembayaran merupakan salah satu yang menjadi pertimbangan dari pembeli atau pelanggan untuk membeli produk yang ditawarkan. Pembeli atau pelanggan akan mempertimbangkan penjual atau produsen mana yang dapat memberikan syarat pembayaran yang lebih lunak dan dapat juga menetapkan harga tersegmentasi.

\section{Strategi Distribusi}

KUB "Kembang Ilung" dapat mencoba mendistribusikan produknya ke pasar-pasar modern, pembukaan showroom dekat dengan konsumen potensial, dan dapat dititipkan di bandara atau di toko-toko souvenir sehingga konsumen memperoleh produk yang diinginkan dengan mudah, tanpa harus datang langsung ke KUB "Kembang Ilung". KUB "Kembang Ilung" dapat mengajak beberapa konsumen potensial, untuk menjadi agen atau reseller dengan memberikan potongan harga tertentu atau prosentase pembagian untung yang cukup menarik. Untuk dapat menjangkau pasar yang luas dan KUB “ Kembang Ilung” perlu mengadakan perencanaan persediaan yang cukup agar operasi usaha dapat berjalan lancer dan efisien.

\section{Strategi Promosi}

Meskipun bisnis KUB "Kembang Ilung" bersifat home industry, tapi promosi dengan menggunakan media iklan cukup penting untuk menarik minat konsumen. KUB “Kembang Ilung” dapat menggunakan spanduk, banner, atau neon box di depan rumah dengan menuliskan nama usaha dan produk-produk yang anda tawarkan sehingga masyarakat yang lewat bisa mengetahui keberadaan produk dari KUB "Kembang Ilung". Selanjutnya KUB "Kembang Ilung" bisa membuat pamflet, kartu nama, dan brosur yang dapat dibagikan di tempat keramaian, tempat penjualan ataupun ketika pameran berlangsung. Selain itu juga, dapat memanfaatkan internet untuk mengiklankan produk kerajinan kepada calon pembeli KUB "Kembang Ilung" dapat memperkenalkan produknya kepada masyarakat luas dengan event-event yang diselenggarakan pihak pemerintah maupun swasta. Kegiatan pameran ini tidak hanya sekedar memperoleh keuntungan saja, namun juga dapat membangun citra positif KUB "Kembang Ilung" di mata masyarakat sebagai usaha kerajinan eceng gondok dengan kualitas baik 
dan dapat mengetahui informasi mengenai pesaing.

\section{KESIMPULAN}

Berdasarkan analisis lingkungan internal usaha KUB "Kembang Ilung” berada pada posisi rata-rata dalam memanfaatkan kekuatan dan kelemahan usaha yang ada. Kekuatan yang paling berpengaruh adalah adanya loyalitas yang baik, sedangkan faktor kelemahan adalah kualitas SDM rendah, terbatas dan kurang fokus. Hasil analisis lingkungan eksternal usaha KUB "Kembang Ilung" berada pada posisi sedang dalam memanfaatkan peluang untuk mengatasi ancaman yang dihadapi. Peluang utama KUB "Kembang Ilung" yaitu pengadaan pelatihan dan pameran serta dukungan pemerintah untuk mencintai produk lokal. Adapun yang menjadi ancaman utama adalah adanya produk substitusi.

Hasil Matris IE berdasarkan analisis lingkungan eksternal dengan menggunakan matrik IFE dengan total skor terbobot sebesar 2,592 sedangkan matrik EFE sebesar 2,674 menunjukkan posisi KUB "Kembang Ilung" berada di kuadran $\mathrm{V}$ yang menggambarkan Hold and Maintain (jaga dan pertahankan). Strategi yang tepat digunakan pada posisi ini adalah strategi penetrasi pasar dan pengembangan produk.

\section{DAFTAR PUSTAKA}

Anonim. 2011. Profil Desa Banyu Hirang. Kecamatan Amuntai Selatan. Kabupaten Hulu Sungai Utara.

David, Fred R. 2010. Manajemen Strategi, Edisi 12. Jakarta: Salemba Empat.

Priastuti. 2011. Proses Pembuatan Kerajinan Tangan Berbahan Eceng Gondok. http://www Indojaya.com. 